\title{
The Labial and Zygomatic Salivary Glands in Mixed Breed Dogs in Trinidad: Anatomical Location, Histological Features and Histochemical Characteristics
}

\author{
Reda Mohamed ${ }^{1,2^{*}}$ \\ ${ }^{I}$ Department of Basic Veterinary Sciences, School of Veterinary Medicine, Faculty of Medical Sciences, The University of the West Indies, St. \\ Augustine, Republic of Trinidad and Tobago \\ ${ }^{2}$ Department of Anatomy and Embryology, Faculty of Veterinary Medicine, Beni-Suef University, Beni-Suef 62511, Egypt \\ *Corresponding author's Email: kkidareda@gmail.com; (DORCiD: 0000-0002-5512-6175
}

\begin{abstract}
The objective of this investigation was to give detailed descriptions of the anatomical location, histological features and histochemical characteristics of the labial and zygomatic salivary glands in mixed breed dogs. This study was performed on five heads of adult mixed breed dogs of both sexes. The heads were dissected to detect in situ position of the labial and zygomatic salivary glands. The glands were dissected and examined grossly. Samples of the glands were taken, processed and stained using hematoxylin and eosin and Masson's Trichrome for histological examination as well as Periodic Acid-Schiff, Alcian Blue (pH 2.5 and 1.0) and a combination of Periodic AcidSchiff and Alcian Blue (pH 2.5 and 1.0) techniques for histochemical examination. The labial and zygomatic salivary glands were located in the lower lip and in the orbit respectively and they were surrounded by fibrous capsules containing collagen fibers. They were minor, compound, mixed tubuloalveolar glands. They composed of mucous acini, mucous acini with serous demilunes and isolated serous acini. The secretion of the glands (chiefly mucous) consisted of neutral mucins, acid carboxylated mucins and acid sulphated mucins. The duct system of the glands was intralobular (intercalated and striated ducts) and interlobular ducts. The anatomical location as well histological and histochemical structures of the labial and zygomatic salivary glands were important to classify the glands and their secretion as well as to give veterinarians knowledge during clinical examination of the oral and orbital regions, and to recognize normal and pathological conditions.
\end{abstract}

Keywords: Anatomy, Dog, Labial, Salivary glands, Zygomatic

\section{INTRODUCTION}

The salivary glands are the accessory structures of the gastrointestinal tract and their exocrine secretion (saliva) prepare ingesta for digestion as it contains mucopolysaccharides, water, enzymes and lubricating glycoprotein (Adnyane et al., 2010; Al-Abbad, 2011). They are developed at various locations with different structures and secretions which are either serous, mucous or seromucous (Jaskoll et al., 2002). The major salivary glands include parotid, mandibular and sublingual, while the minor salivary glands include the lingual, buccal and labial salivary glands, which are found in the lingual, buccal and labial mucosa respectively (Kimura et al., 1998; Popovici et al., 2003; Barone, 2009; Miclăuş, 2012). The diversity of structures and secretions of the salivary glands depends on the animal's feeding habits (Tandler and Phillips, 1998). Zygomatic and molar glands are major salivary glands which are present in carnivores and cat respectively (Dyce et al., 2004; Mohammadpour, 2010). However, in other animals the zygomatic glands are classified either as minor (Dellman and Eurell, 1998) or major (Evans and Christensen, 1979). Tumors of salivary glands have been reported in the horse, cattle, sheep, goat, dog and cat (Head, 1976; Carberry et al., 1988). Pleomorphic labial gland adenoma was recorded in a dog (Izawa et al., 2017). Zygomatic gland mucocele associated with exophthalmos is less common in dogs (McGill et al., 2009 and Cannon et al., 2011); however, it was reported in a cat and ferret (Miller and Pickett. 1989; Speakman et al., 1997). Zygomatic salivary glands tumors in the orbit of the dog were recorded previously (Buyukmihci et al., 1975; Attali-Soussay et al., 2001). There is no available study documenting the histomorphological and histochemical features of the labial and zygomatic salivary glands in mixed breed dogs. It is important for veterinarians to recognize normal and pathological conditions during examination and investigation of the oral and orbital cavities of dogs. Moreover, the labial gland is used in autologous transplant to stimulate the lubrication of the ocular surface and the zygomatic salivary glands problems can cause exophthalmos.

So the present study aimed to indicate the anatomical location, histological aspect and histochemical features of the labial and zygomatic salivary glands of mixed breed dogs. 
A total of five apparently healthy adult mixed breed dogs ( 3 males and 2 females) were used for the current study. Fresh euthanatized dogs with pentobarbital $(1 \mathrm{ml} / 4.5 \mathrm{~kg}$, IV) were obtained from the Trinidad and Tobago Society for the Prevention of Cruelty to Animals (TTSPCA) and transferred to the anatomy laboratory, School of Veterinary Medicine, The University of the West Indies, Trinidad and Tobago. The head of each dog was dissected by removing the bony structures such as the zygomatic arch and mandible, followed by the removal of the masseter, temporalis and pterygoid muscles. The labial and zygomatic glands were dissected and excised from the adhering tissues. The position of the glands and their related structures were described and photographed using a Sony 12 megapixel digital camera (Sony Coporation, Japan). Tissue specimens were taken from the labial and zygomatic glands and fixed in $10 \%$ neutral buffered formalin for 24-48 hours, then dehydrated in ascending grades of ethanol, cleared in xylene and then embedded in paraffin blocks. Sections of $5 \mu \mathrm{m}$ thickness were prepared using a microtome and stained by hematoxylin eosin for general histological examination and Masson's trichrome stain for detecting collagen fibers (Culling et al., 1985). Periodic Acid-Schiff (PAS), Alcian Blue (AB pH 2.5 and 1.0) and AB-PAS (pH 2.5and 1.0) techniques were used to detect and differentiate the types of the secretion of the labial and zygomatic salivary glands (Culling et al, 1985; Cunha et al., 2016). The stained sections were observed under a light microscope (Olympus BX40 with an Olympus DP 15 megapixel digital camera, Japan) at different magnifications and photomicrographs were taken.

\section{Ethical approval}

The ethical approval from the University of the West Indies, St. Augustine, Trinidad and Tobago ethical committee (CEC906/02/19) was obtained.

\section{RESULTS}

\section{Anatomical location}

The labial salivary gland of the mixed breed dogs was a lobulated gland located in the lower lip. It extended from the lower second premolar tooth to the distal edge of the lower molar tooth. The gland was located within the connective tissue, deeply embedded in the mucosal lining of the vestibular cavity (Figure 1). The zygomatic salivary gland was present as a pyramidal, lobulated organ in each side of the head. It was located ventrolaterally in the orbit, under the rostral end of the zygomatic arch and dorsolaterally to the pterygoideus muscles. It was covered by adipose tissue and encapsulated. The medial surface of the gland was slightly grooved by the maxillary vessels and nerve (Figure 1).

\section{Histological features}

The zygomatic and labial salivary glands of the mixed breed dogs were enclosed in a well-developed capsule containing collagen fibers. Interlobular connective tissue septae were originated from the tunica albuginea dividing the gland into various sized lobules (Figure 2). The labial and zygomatic salivary glands were compound, exocrine, tubuloacinar mixed glands containing mucous acini, mucous acini with serous demilunes (mixed seromucous units) and sporadic serous acini. The mucous secretory units, which secrete only mucous, were predominant. The mucous cells had basally located, flattened nuclei with foamy cytoplasm. The serous demilunes with cells had rounded central nuclei and were capped as a half-moon on the mucous cells. The sporadic serous acini showed rounded nuclei with dark cytoplasm. Myoepithelial cells and were present as spindle-shaped cells incorporated between the basement membrane and epithelium of the secretory cells. The ducts of the labial and zygomatic salivary glands were intralobular and interlobular. The intralobular ducts consisted of intercalated and striated ducts which were lined by cuboidal epithelium and tall columnar cells with basal striation respectively. The interlobular ducts were the main excretory ducts in the labial and zygomatic salivary glands. They were lined by stratified columnar epithelium and they were situated in the connective tissue septum between the gland's lobules (Figure 2).

\section{Histochemical characteristics}

The histochemical evaluation of the labial and zygomatic salivary glands showed that the mucous secretory units and serous demilunes in the seromucous acini and sporadic serous clusters as well as the striated ducts were positive to the PAS stain and looked magenta red due to the presence of the neutral mucins (Table 1 and figures 3 and 4). The mucous secreting cells were positive to $\mathrm{AB}(\mathrm{pH} 2.5)$ due to the presence of the acid mucins with strongly staining of acid carboxylated mucins (Figures 3 and 4) and to the $\mathrm{AB}(\mathrm{pH} 1.0)$ due to the presence of the acid sulphated mucins and looked blue (Figures 3 and 4). The combination of AB-PAS showed that the mucous cells stained reddish purple at $\mathrm{pH}$ 2.5 (Figures 3, 4 and 5 and bluish purple at $\mathrm{pH} 1.0$ (Figures 3, 4 and 5). On the other hand, the reaction of the serous demilunes (Figures 3 and 5) were negative to $\mathrm{AB}$ (pH 2.5 and 1.0). 
Table 1. Histochemical features of the mucous secretory units and serous demilunes of the labial and zygomatic salivary glands in the mixed breed dogs in Trinidad

\begin{tabular}{lccc}
\hline & \multicolumn{2}{c}{ Labial salivary gland } & \multicolumn{2}{c}{ Zygomatic salivary gland } \\
\cline { 2 - 4 } Technique / Gland & $\begin{array}{c}\text { Mucous secreting } \\
\text { cells }\end{array}$ & Serous demilunes & $\begin{array}{c}\text { Mucous secreting } \\
\text { cells }\end{array}$ \\
\hline PAS & + & + & + \\
Alcian Blue (pH 2.5) & + & - & + \\
Alcian Blue (pH 1.0) & + & - & + \\
AB-PAS (pH 2.5) & + & - & + \\
AB-PAS (1.0) & + & - & - \\
\hline PAS:Perous demilunes & & - \\
\hline
\end{tabular}

PAS: Periodic Acid-Schiff; AB: Alcian Blue; +: positive staining; -: negative staining
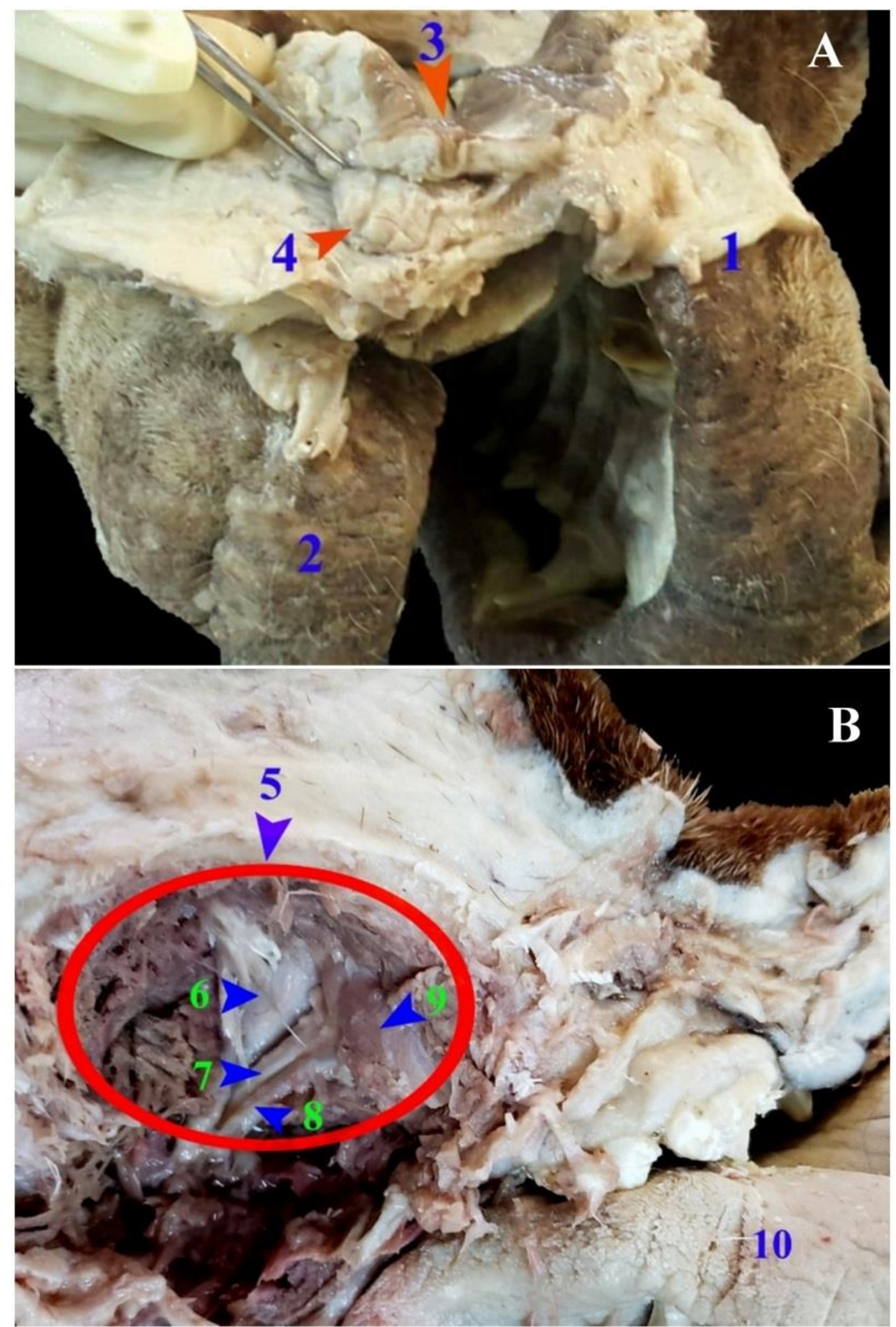

Figure 1. Photographs showing the location of the labial (A) and zygomatic (B) salivary glands in the mixed breed dog. 1: Upper lip; 2: Lower lip; 3: Labial commissure; 4: Labial salivary gland; 5: Orbital cavity; 6: Eye ball; 7: Maxillary nerve; 8: Maxillary artery; 9: Zygomatic salivary gland; 10: Tongue. 


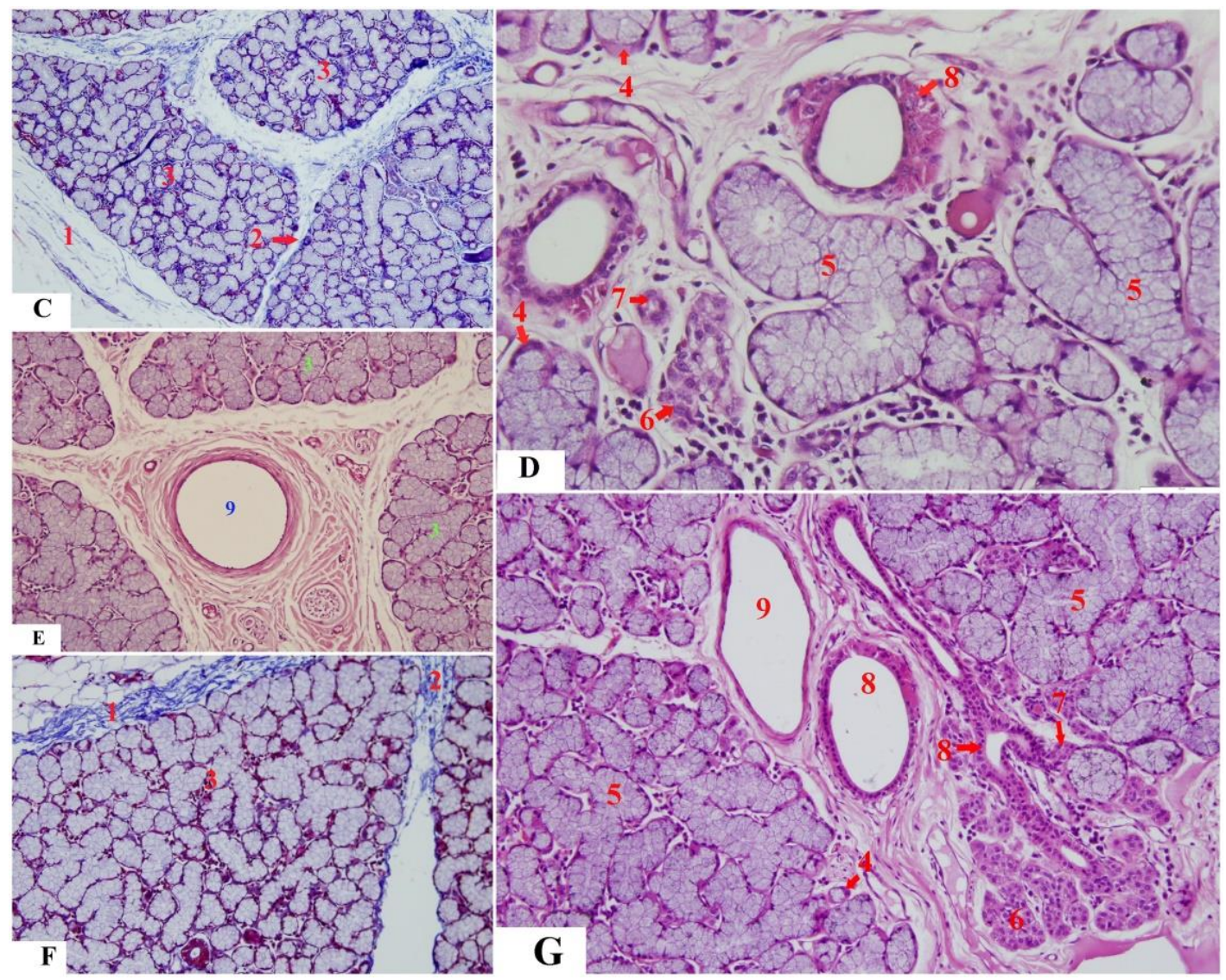

Figure 2. Photomicrographs showing the general histology of the labial (C, E and D) and zygomatic (F and G) salivary glands of the mixed breed dog stained with H \& E (DX40; E x 20 and GX20) and Masson's Trichrome stain (CX10 and FX20). 1: Connective tissue capsule containing collagen fibers; 2: Interlobular septum; 3: Gland lobules; 4: Serous demilunes; 5: Mucous secretory units; 6: Serous acini clusters; 7: Intercalated duct; 8: Striated duct; 9: Interlobular duct.
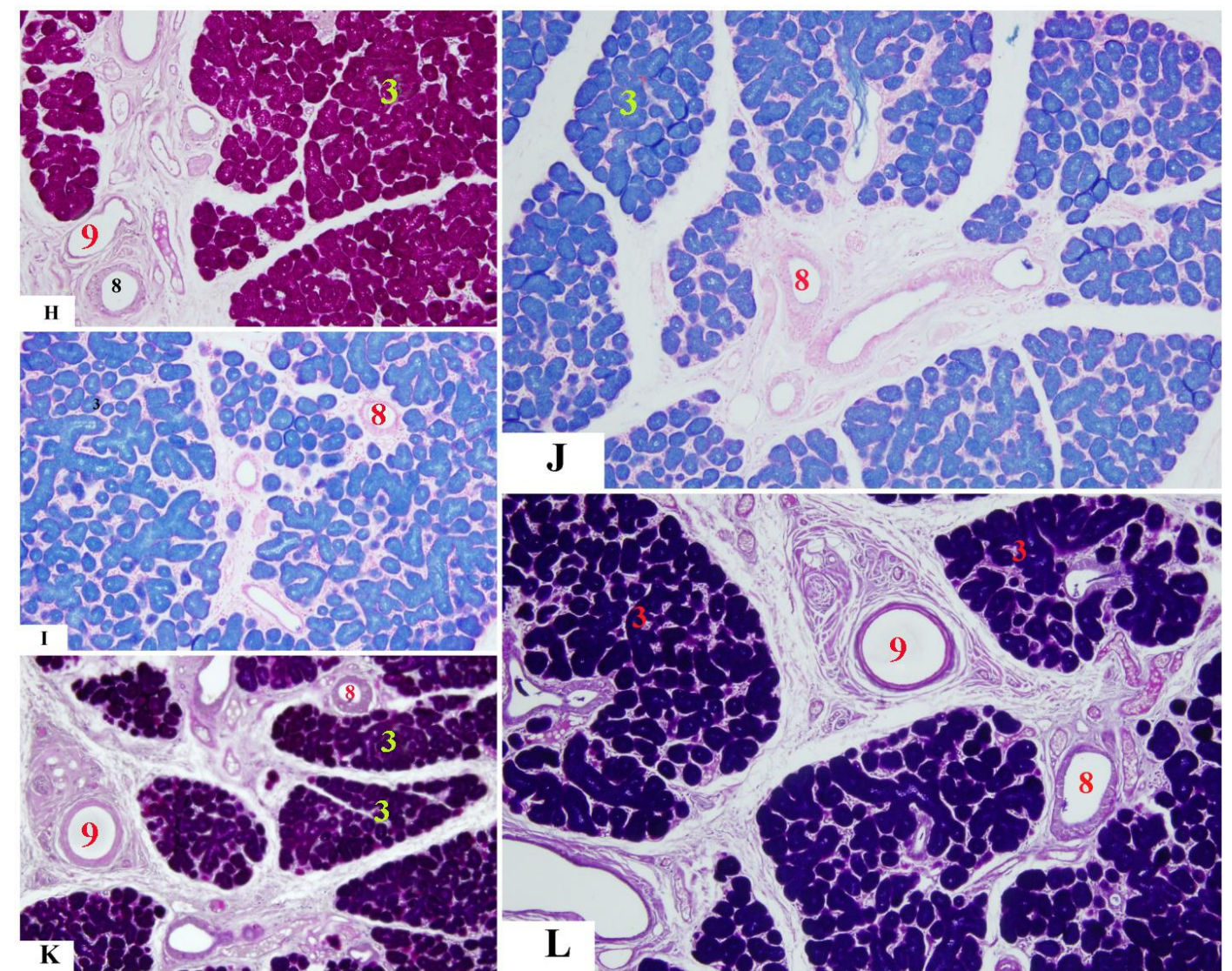

Figure 3. Photomicrographs showing the histochemical characteristics of the mucous secreting cells of the labial salivary gland of the mixed breed dog stained with PAS (HX10), AB (pH 2.5, I X10 and pH 1.0, JX10) and AB-PAS (pH 2.5, KX10 and pH 1.0, LX10). 3: Gland lobules; 7: Intercalated duct; 8: Striated duct; 9: Interlobular duct. 


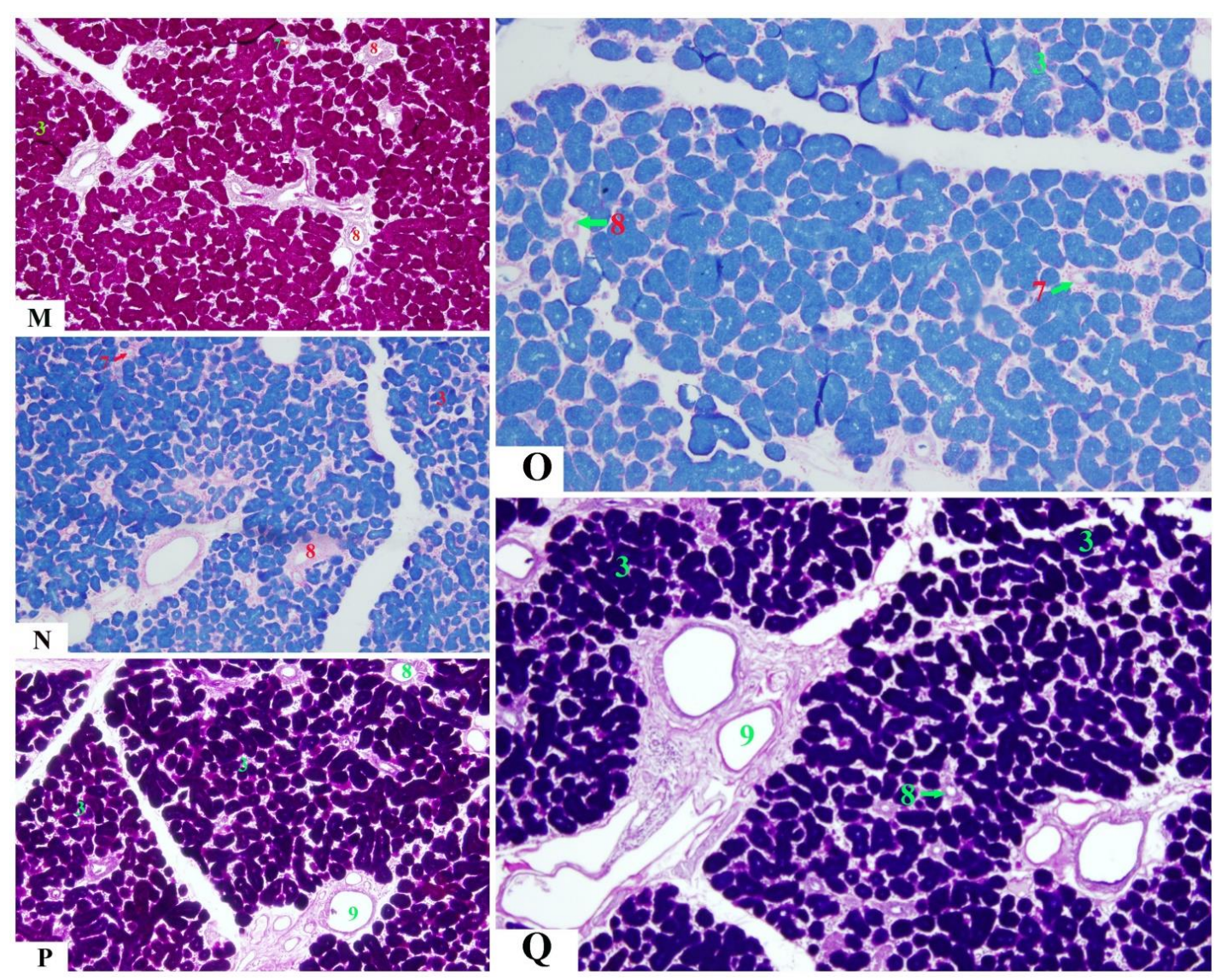

Figure 4. Photomicrographs showing the histochemical characteristics of the mucous secreting cells of the zygomatic salivary gland of the mixed breed dog stained with PAS (MX10), AB (pH 2.5, N X10 and pH 1.0, OX10) and AB-PAS (pH 2.5, PX10 and pH 1.0, QX10). 3: Gland lobules; 8: Striated duct; 9: Interlobular duct.

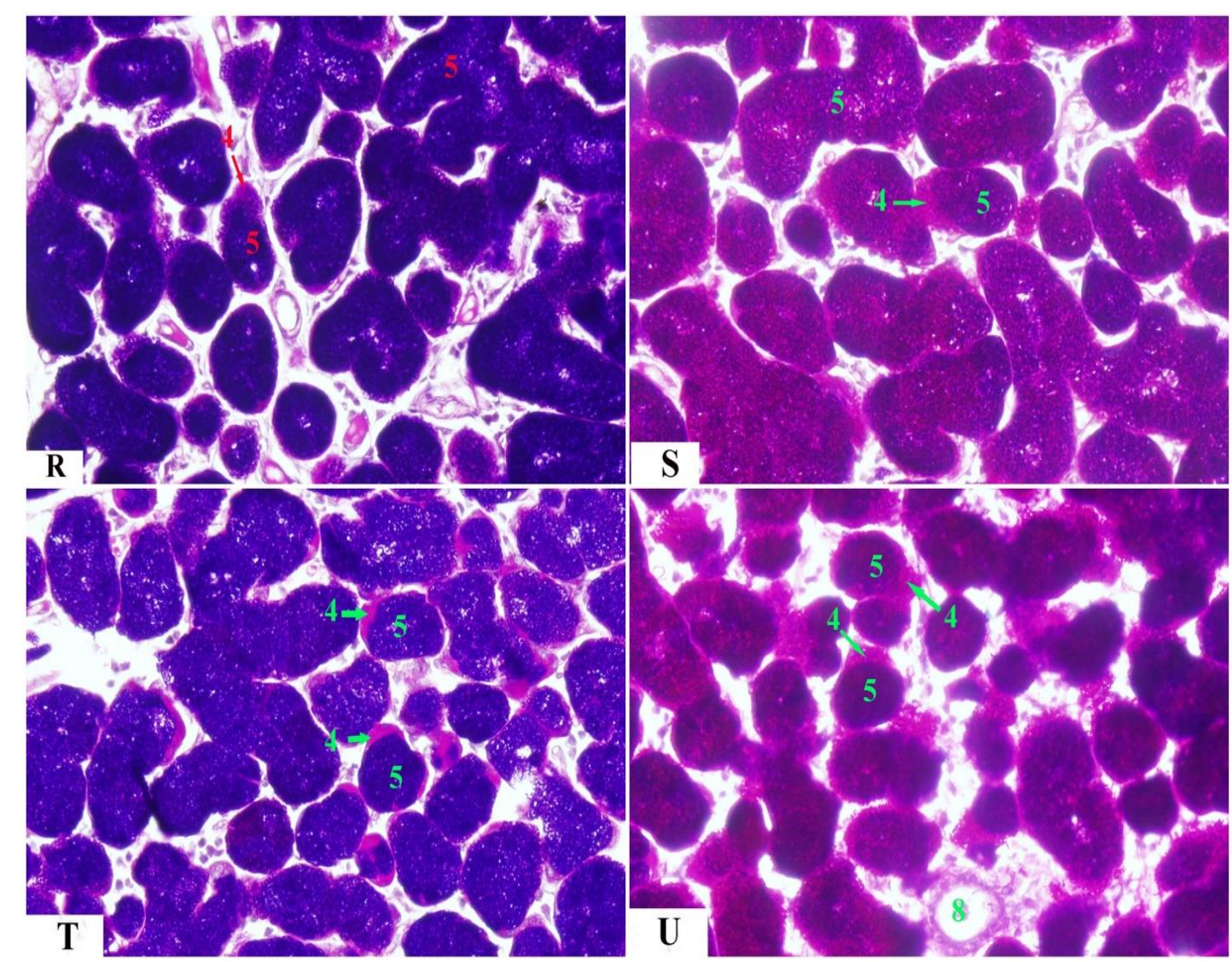

Figure 5. Photomicrographs showing the histochemical characteristics of the mucous secreting cells and serous demilunes of the labial salivary gland ( $\mathrm{R}$ and $\mathrm{S}$ ) and zygomatic salivary gland ( $\mathrm{T}$ and $\mathrm{U}$ ) of the mixed breed $\operatorname{dog}$ stained with AB-PAS (pH 1.0, R and TX40 and $\mathrm{pH} 2.5, \mathrm{~S}$ and UX40). 4: Serous demilunes; 5: Mucous secretory units; 8: Striated duct. 
There was not much available literature reporting on the labial and zygomatic salivary glands of mixed breed dog in Trinidad. However, the zygomatic salivary gland of the Philippine non-descript dog and the labial salivary gland of the dog (Maala et al., 2008; Cunha et al., 2016) respectively were described.

The present results as well as that in dog (Angélico et al., 2011; Rocha, 2012 and Cunha et al., 2016) stated that the labial salivary gland was easily palpable in the lower lip between the lower second premolar and the second molar teeth. Moreover, the zygomatic salivary gland of the mixed breed dog was a pyramidal shaped gland located inside the orbit. Similar result was observed in mesaticephalic dog (Diesem, 1975). However, Maala et al. (2008) reported the same location but the gland was irregular in shape in the Philippine non-descript dog.

The labial and zygomatic salivary glands were surrounded by a connective tissue capsule with collagen fibers; a similar result is noticed in the labial salivary gland of the dog (Rocha, 2012; Cunha et al., 2016), zygomatic salivary gland of the dog (Maala et al., 2008), labial gland of the buffalo (Jabbar, 2010) and molar salivary gland in domestic cat (Mohammadpour, 2010). On the other hand, the minor salivary glands are lack of connective tissue capsule (Bacha and Bacha, 2003). Moreover, the labial and zygomatic salivary glands were divided into lobules by the connective tissue which surrounded and intermingled the gland as mentioned in the rat (Hand et al., 1999), labial salivary gland of the dog (Cunha et al., 2016), zygomatic salivary gland of the dog (Maala et al., 2008), labial salivary gland of the buffalo (Jabbar, 2010) and molar salivary gland in domestic cat (Mohammadpour, 2010).

Similar to the observations in the labial salivary gland in the dog (Rocha, 2012; Cunha et al., 2016), zygomatic salivary gland in the dog (Dellmann and Eurell, 1998; Maala e al., 2008; Gomi et al., 2017), zygomatic salivary gland in the Leopard and cat (Sadeghinezhad et al., 2016), molar salivary gland in the domestic cat (Mohammadpour, 2010) and Weber's salivary gland of the rabbit (Haddao and Yasear, 2018), the secretion of the labial and zygomatic salivary glands of the mixed breed dog was mixed and primarily mucous. However, the secretion is classified as mucous in the $\operatorname{dog}$ (Banks, 1991). However, the labial salivary gland is serous glands in the buffalo (Jabbar, 2010) and in the Giant rat (Asojo and Aire, 1983). On the other hand, the labial gland has mucoserous acini capped by serous demilunes in the camel (Taib and Jarrar, 1987). On the other hand, the secretion of the zygomatic gland of the Japanese serow is chiefly serous (Tsuchimoto et al., 1984).

The current study as well as Cunha et al. (2016) and Gomi et al. (2017) in the dog and Jabbar (2010) in the buffalo stated that the secretions of the labial and zygomatic salivary glands pass via the intralobular (intercalated and striated) and interlobular ducts. However, Frappier (2006) mentioned that the minor salivary glands are lacking in striated ducts. However, the intercalated duct was absent in the zygomatic salivary gland, while the intralobular and interlobular ducts were present; the former ones appeared as oval ducts, lined by cuboidal epithelium, without basal striations in dog (Dellmann and Eurell, 1998; Maala e al., 2008) and in the labial gland of the camel (Taib and Jarrar, 1987). On the other hand, there are no intercalated or striated ducts in molar salivary gland in domestic cat (Mohammadpour, 2010). The striated duct is absent in the Weber's salivary gland of the rabbit (Haddao and Yasear, 2018).

In the samples of the current study of the labial and zygomatic salivary glands of the mixed breed dog showed that the mucous secretory units and serous demilunes secrete neutral mucins as they were positive to PAS stain. All acid mucous of the mucous secretory units was positive to $\mathrm{AB}(\mathrm{pH} 2.5)$ with strongly staining of acid mucins, while acid, sulphated mucins were stained by $\mathrm{AB}$ ( $\mathrm{pH} 1.0)$. Similar results were observed in the labial salivary gland in the dog (Giudice et al., 2005; Cunha et al., 2016), zygomatic salivary gland in the dog (Sozmen et al., 1999; Maala e al., 2008) and labial salivary gland of the buffalo (Jabbar, 2010) and camel (Taib and Jarrar, 1987). However, the mucous acini of the weber's salivary gland of the rabbit were negative to PAS and AB (1.0) while the mucous acini and serous cells were positive to PAS (Haddao and Yasear, 2018).

The current study showed that the combination of PAS-AB stain showed that the mucous cells of the labial and zygomatic salivary glands stained bluish purple at $\mathrm{pH} 1.0$ and reddish purple at $\mathrm{pH} 2.5$ which indicated that mucous cells secrete neutral mucins more than acidic mucins. Moreover, the mucous cells secrete large amounts of acidic sulphated mucins; similar results were reported in the zygomatic salivary of the dog (Sozmen et al., 1999). However, Maala et al. (2008) stated that the zygomatic salivary gland secretes small amount of acidic sulphated mucins. On the other hand, the mixed mucins of the mucous cells of the zygomatic salivary glands are more acidic in leopard and cat (Sadeghinezhad et al., 2016). However, the weber's salivary gland secretes acidic mucins from the mucous cells and neutral mucins from the serous cells (Haddao and Yasear, 2018).

The mucin of the labial salivary glands was characterized by its high viscosity, low solubility and stickiness which made them able to lubricate the mucosa of the food passage and prevent its drying. Furthermore, it facilitates the passage of the food from the mouth to the esophagus by coating food boluses and keeping the integrity while protecting the mucosa of the pharynx and esophagus from mechanical injury. Similar findings were mentioned by Samar et al. (1995), Maala e al. (2008), Munyala et al. (2009) and Cunha et al. (2016). 


\section{CONCLUSION}

The labial and zygomatic salivary glands of mixed breed dogs were tubuloacinar with mixed seromucous secretions. The duct system consists of intercalated, striated and interlobular ducts in the labial salivary and zygomatic salivary glands. The secretions of the glands were composed of neutral, acid carboxylated and acid sulphated mucins.

\section{DECLARATIONS}

\section{Competing interests}

The author declared that there is no conflict of interests.

\section{Acknowledgements}

This work was supported by the Department of Basic Veterinary Sciences under the school of Veterinary Medicine, The University of the West Indies, St. Augustine, Trinidad and Tobago.

\section{REFERENCES}

Adnyanev IKM, Zuk AB, Noordin MM and Agungpriyono S (2010). Histological study of the parotid and mandibular glands of barking deer (Muntiacus muntjak) with special reference to the distribution of carbohydrate content. Anatomia Histologia Embryologia, 39: 516-520. DOI: https://doi.org/10.1111/j.1439-0264.2010.01023.x

Al-Abbad MA (2011). Salivary gland cytology: A color atlas. John Wiley \& Sons, Inc, Hoboken, New Jersey.

Angélico GT, Ranzani, JJT, Brandão CVS, Schellini AS and Padovani CR (2011). Transplante de glândulas salivares menores no tratamento da ceratoconjuntivite seca em cães. Arquivo Brasileiro de Medicina Veterinária e Zootecnia, Belo Horizonte, 63 (5): 1087-1092. DOI: https://doi.org/10.1590/S0102-09352011000500007

Asojo TA and Aire TA (1983). Microsterological and histo-chemical studies of the salivary glands of the Giant Rat ,Cricetomys gambianus, (Waterhouse). Acta Anatomica, 117: 65-72

Attali-Soussay K, Jegou JP and Clerc B (2001). Retrobulbar tumors in dogs and cats: 25 cases. Veterinary Ophthalmology, 4(1): 19-27. DOI: https://doi.org/ 10.1046/j.1463-5224.2001.00123.x

Bacha WJ and Bacha LM (2003). Sistema digestório. In: Atlas colorido de histologia veterinária. 2. ed. São Paulo: Roca, cap. 13, Pp. 195-273.

Banks WJ (1991). Epitélios. Sistema digestivo II - órgãos extramurais. In: Histologia veterinária aplicada. 2. ed. São Paulo: Manole, 1991a. cap. 22, pp. 465-480.

Barone R (2009). Anatomie comparée des mammifères domestiques. Tome 3, Splanchnlogie I, Appareil digestif. Appareil respiratoire. Vigot, Paris

Buyukmihci N, Rubin LF and Harvey CE (1975). Exophthalmos secondary to zygomatic adenocarcinoma in a dog. Journal of the American Veterinary Medical Association, 167(2): 162-165.

Cannon MS, Paglia D, Zwingenberger AL, Boroffka SA, Hollingsworth SR and Wisner ER (2011). Clinical and diagnostic imaging findings in dogs with zygomatic sialadenitis: 11 cases (1990-2009). Journal of the American Veterinary Medical Association, 239: 1211-1218. DOI: https://doi.org/ 10.2460/javma.239.9.1211

Carberry CA, Flanders JA, Harvey HJ and Ryan AM (1988). Salivary gland tumors in dogs and cats: a literature and case review. The Journal of the American Animal Hospital Association, 24: 561-567.

Culling CFA, Allison RT and Barr PJ (1985). Cellular pathology technique, 4th ed, Butterworth \& Co. Publishing Ltd, pp. $221-261$.

Dellmann HD and Eurell J (1988). Textbook of veterinary histology, 5th ed, Baltimore: Lippincott Williams and Wilkins

Diesem C (1975). Carnivore sense organs and common integument. In chapter 58: Sisson and Grossman's The anatomy of domestic animal (R. Getty,ed.). Vol.2. Tronto: W.B, Saunders Co.

Dyce KM, Sack WO and Wensing CJG (2004). Aparelho digestório. In: Tratado de anatomia veterinária. 3. ed. Rio de Janeiro: Elsevier cap. 3, pp. 99145.

Evans HE and Christensen HC (1979). Miller's anatomy of the dog. Philadelphia: W.B. Saunders Co.

Frappier BL (2006). Digestive system. In: Eurell JA, Frappier BL(Ed.). Dellmann's textbook of veterinary histology. 6th ed. Iowa: Blackwell, Pp. 170211.

Galvão SR, Cunha DNQ, Carlo, RJD, Borges APB, Benjamin LDA, Fonseca CC, Marcon L and Pereira CER (2016). Morphological, morph ometric and histochemical aspects of the labial salivary glands of dogs. Semina: Ciências Agrárias, Londrina, 37 (5): $3079-3086$. https://doi.org/10.5433/1679-0359.2016v37n5p3079

Giudice C, Marco R, Mirko R, Luca M and Giorgio C (2005). Zygomatic gland adenoma in a dog: histochemical and immunohistochemical evaluation. Veterinary Ophthalmology, 8 (1): 13-16. DOI: https://doi.org/ 10.1111/j.1463-5224.2005.04058.x]

Gomi H, Osawa H, Uno R, Yasui T, Hosaka M, Torii S and Tsukise A (2017). Canine salivary glands: analysis of rab and snare protein expression and snare complex formation with diverse tissue properties. Journal of Histochemistry \& Cytochemistry, 65(11): 637-653. DOI: https://doi.org/10.1369/0022155417732527

Haddao KM and Yasear AY (2018). Weber's salivary glands of rabbit: histological and histochemical studies. Biochemical and Cellular Archives , 18 (5): 557-560.

Hand AR, Pathmanathan D and Field RB (1999). Morphological features of the minor salivary glands. Archives of Oral Biology, 44 (1): S3-S10. DOI: https://doi.org/10.1016/S0003-9969(99)90002-X

Head KW (1976). Tumors of the upper alimentary tract. Bulletin of the World Health Organization, 53(2-3): 145-166.

Jabbar AI (2019). Histological and certain histochemical observations on the labial salivary glands of the buffalo, bubalus bubalis. Al-Qadisiyah Journal of Veterinary Medicine Sciences, 9(1): 17-23.

Jaskoll T, Zhou YM, Chai Y, Makarenkova HP, Collinson JM, West JD and Carvalho AD (2002). Embryonic submandibular gland morphogenes is; Stage- specific protein localization of FGFs, BMPs, Pax6 and Pax9 in normal mice and abnormal phenotypes in FgfR2- III c(t/Delta), BMP7(-/-) and Pax6(-/-) mice. Cells Tissues Organs, 170: 83-90. DOI: https://doi.org/10.1159/000046183 
Kimura J, Habata I, Endo H, Rerkamnuagchoke W, Kurohmaru M, Yamada J, Nishida T and Tsukise A (1988). Histochemistry of comoplex carbohydrate in the major salivary glands of Hoary Bamboo rats (Rhizomys purinosus). Anatomia Histologia Embryologia, 27: 147-153. DOI: https://doi.org/10.1111/j.1439-0264.1998.tb00172.x

Kuramochi M, Izawa T, Nishimura S, Shimada T, Kuwamura M and Yamate J (2017). Pleomorphic adenoma of the labial gland, characterized by reticular pattern of myoepithelial cells in a dog. The Journal of Veterinary Medical Science, 79 (7): 1163-1166. DOI: https://doi.org/10.1292/jvms.17-0117

Maala CP, De Ocampo GD and Ureta JV (2008). Gross and microscopic characterization of the zygomatic salivary gland of the Philippine non-descript dog. Philippine Journal of Veterinary Medicine, 45: 1-6.

McGill S, Lester N, McLachlan A and Mansfield C (2009). Concurrent sialocoele and necrotising sialadenitis in a dog. Journal of Small Animal Practice, 50: 151-156. DOI: https://doi: 10.1111/j.1748-5827.2009.00706.x.

Miclăuș V (2012). Histologie specială și embriologie generală, Ediția a 2-a revizuită. Editura Risoprint, Cluj-Napoca.

Miller PE and Pickett JP (1989). Zygomatic salivary gland mucocele in a ferret. Journal of the American Veterinary Medical Association, 194:14371438.

Mohammadpour AA (2010). Anatomical and histological study of molar salivary gland in domestic cat. Iranian Journal of Veterinary Research, 11 (2): 164-167. DOI: https://doi.org/10.22099/IJVR.2010.160

Munyala R, Liumsiricharoen M, Pongket P, Prapong T and Suprasert A (2009). Glycoconjugates in the secretory epithelium of the mandibular salivary gland of Malayan Pangolin (Manis javanica). KKU Veterinary Journal, Khon Kaen, 19 (2): 162-169.

Popovici I, Damian A, Popovici N and Ioana C (2003).Tratat de anatomie comparată. Splanhnologie. Editura Academic Press, Cluj-Napoca.

Rocha GLS (2012). Transplante autólogo das glândulas salivares labiais, oclusão cirúrgica dos pontos lacrimais ou associação das duas técnicas no tratamento da ceratoconjuntivite seca em cães. Tese (Doutorado em Cirurgia e Oftalmologia) - Universidade Federal de Minas Gerais, Belo Horizonte.

Sadeghinezhad J, Sheibani MT and Memarian I (2016). Histological and Mucin Histochemical Characteristics of the Zygomatic Salivary Gland of Persian Leopard (Panthera Pardus Saxicolor) and Domestic Cat (Felis Silvestris Catus). Anatomical Sciences, 13(2):125-130.

Samar ME, Avila RE, Fabro SPde and Centurion C (1995). Structural and cytochemical study of salivary glands in the Magellanic Penguin Spheniscus magellanicus and the Kelp Gull Larus dominicanus. Marine Ornithology Burnaby, 23 (2):153-156.

Sozmen M, Brown PJ and Cripps PJ (1999). Quantitation of histochemical staining of salivary gland mucin using image analysis in cats and dogs. Veterinary Research, BioMed Central, 30 (1): 99-108. DOI https://hal.archives-ouvertes.fr/hal-00902560

Speakman AJ, Baines SJ, Williams JM and Kell DF (1997). Zygomatic salivary cyst with mucocele formation in a cat. Journal of Small Animal Practice 38: 468-470. DOI:https://doi.org/0.1111/j.1748-5827.1997.tb03444.x

Taib NT and Jarrar BM (1987). The histochemistry of labial salivary glands of one-humped camel, Camelus dromedaries. Bollettino di zoologia, 54 : 19-25. DOI: https://doi.org/10.1080/11250008709355551

Tandler B and Phillips CJ (1988). Microstructure of mammalian salivary glands and its relationship to diet. In:Garrett JR, Ekström J, Anderson LC, editors. Glandular mechanisms of salivary secretion. Front Oral Biol. Basel: Karger, 10. Pp. 21-35.

Tsuchimoto N, Sugano M, Atoh Y, Suzuki Y and Sogimoro M (1984). Zygomatic salivary gland in Japanese serow, Capricornis crispus. Japanese Journal of Veterinary Science, 46: 593-596. DOI: https://doi.org/0.1292/jvms1939.46.593 